\title{
Endogenous tidal rhythms of vertical migration in field collected zoea-1 larvae of the shore crab Carcinus maenas: implications for ebb tide offshore dispersal
}

\author{
Chaoshu Zeng*, Ernest Naylor \\ School of Ocean Sciences, University of Wales, Bangor, Menai Bridge, Gwynedd LL59 5EY, United Kingdom
}

\begin{abstract}
Employing a highly sensitive infra-red light actography system, circatidal rhythms of vertical migration were recorded in first stage zoea larvae of the common shore crab Carcinus maenas (L.), freshly collected from coastal waters. The rhythms persisted in constant conditions in the laboratory for several days, ascent occurring at the times of expected ebb tides at collection sites, and descent during expected flood tides. Timing was identical in larvae sampled at different stage of spring/neap cycle and from sites where different hydrodynamic conditions prevail. These experiments, supported by repeated surface plankton samples which confirmed that zoea-1 larvae of $C$. maenas were most abundant at the surface during ebb tides, suggest that the vertical migration behaviour might be linked with avoidance of stranding and offshore dispersal of newly released larvae. The fact that tidal migration rhythm was exhibited by larvae collected from different sites implies that the behaviour is probably widespread for the species. So far, endogenous tidal rhythms of vertical migration in plankton have been demonstrated solely in a few estuarine forms, and have been interpreted only as estuarine retention or reinvasion mechanisms. Present results appear to be the first to demonstrate that endogenous tidal rhythms also exist in the planktonic larvae of a coastal invertebrate and suggest that these larvae may have an adaptive mechanism to avoid stranding and enhance offshore dispersal in the open sea.
\end{abstract}

KEY WORDS: Carcinus maenas Zoea-1 Tidal vertical migration - Endogenous - Timing Surface abundance Dispersal Avoidance of stranding

\section{INTRODUCTION}

Diel vertical migration in plankton has been recognized for more than a century (Longhurst 1976), but it is only relatively recently that plankton vertical migration over tidal timescales has been reported. The latter has been typically reported in the context of retention and reinvasion mechanisms for the larvae of species which as adults occur in estuaries. Field surveys in estuaries have reported such behaviour in the larvae of molluscs (Carriker 1951, 1961, Wood \& Hargis 1971), Crab zoeae (DeCoursey 1976, Cronin \& Forward 1982). crab megalopae (Epifanio et al. 1984, Brookins \& Epi-

•E-mail: osp043@sos.bangor.ac.uk fanio 1985, Mense \& Wenner 1989, Dittel \& Epifanio 1990, Little \& Epifanio 1991, De Vries et al. 1994, Olmi 1994, Queiroga et al. 1994), penaeid postlarvae (Young \& Carpenter 1977, Rothlisberg et al. 1995) and planktonic copepods (Wooldridge \& Erasmus 1980, Hough \& Naylor 1991). However, no attention appears to have been paid to the possible occurrence of tidal vertical migration in the larvae of open coast species.

Theoretically, if a coastal planktonic organism exhibits vertical migration rhythms that are exactly synchronized with the tidal period in tidal currents, a particularly efficient unidirectional transport mechanism results. Moreover, depending on the phase of the vertical migration, the direction of transport could be with either the flood tide or the ebb tide direction of flows (Hill 1991a, b, 1995). This suggests that tidal vertical 
migration is worthy of investigation in planktonic larvae of coastal invertebrates as a possible mechanism for assisting dispersal or recruitment.

The biology and ecology of juveniles and adults of the shore crab Carcinus maenas, commonly found on coasts and estuaries of Northwest Europe and Northeast America (Crothers 1968, Berril 1982), are well documented (Broekhuysen 1936, Naylor 1962, Crothers 1968, Klein-Breteler 1975, 1976, Thiel \& Dernedde 1994). However, whilst larval dispersal and recruitment in other crab species have attracted much attention in recent years (Johnson \& Gonor 1982, Provenzano et al. 1983, Johnson 1985, Shanks 1985, Epifanio 1988a, b, McConaugha 1988, 1992, Little \& Epifanio 1991, Hobbs \& Botsford 1992, Hobbs et al. 1992, McConnaughey et al. 1992, De Vries et al. 1994. Olmi 1994, Tankersley \& Forward 1994), these processes have been largely ignored in C. maenas, except for a recent field study concerning larval dynamics of the species in an estuary (Queiroga et al. 1994).

The present work aimed to investigate the vertical migration behaviour of newly released larvae of Carcinus maenas from coastal waters. Our preliminary observations revealed that these larvae are dispersed seawards, as was also shown by Queiroga et al. (1994) in a Portuguese estuary. We also sought by laboratory experiments to ascertain whether any vertical migration rhythms exhibited by $C$. maenas were endogenous. Harris (1963) and Enright \& Hamner (1967) have published evidence for endogenous control of diel vertical migration in open sea plankton and Cronin \& Forward (1979), Hough \& Naylor (1992) and Tankersley \& Forward (1994) reported endogenous control of tidal migration rhythms of estuarine plankton species. However, there are, so far, no reports of endogenous circatidal rhythms in an open sea plankton species.

\section{MATERIALS AND METHODS}

Laboratory studies of larval tidal vertical migration rhythms. Collection of crab larvae: The first stage zoea larvae of Carcinus maenas were collected from 3 different sites along the Menai Strait and Cardigan Bay, North Wales, UK, during May to July 1994. Site 1 is located between Menai Bridge and Beaumaris in the Menai Strait $\left(53^{\circ} 13^{\prime} \mathrm{N}, 04^{\circ} 09^{\prime} \mathrm{W}\right)$, close to the northeast end of the Strait. At this site, a series of collections was taken at different stages of semilunar (spring/ neap) cycles. Additional collections were taken at 2 other sites, one (Site 2) at Traeth Malynog $\left(53^{\circ} 09^{\prime} \mathrm{N}\right.$, $04^{\circ} 19^{\prime} \mathrm{W}$ ), at the opposite southwest end of the Menai Strait where high tides occur roughly $1 \mathrm{~h}$ earlier than that at Site 1, and another (Site 3) near Pwllheli $\left(52^{\circ} 50^{\prime} \mathrm{N}, 04^{\circ} 25^{\prime} \mathrm{W}\right)$ on the coast of Cardigan Bay

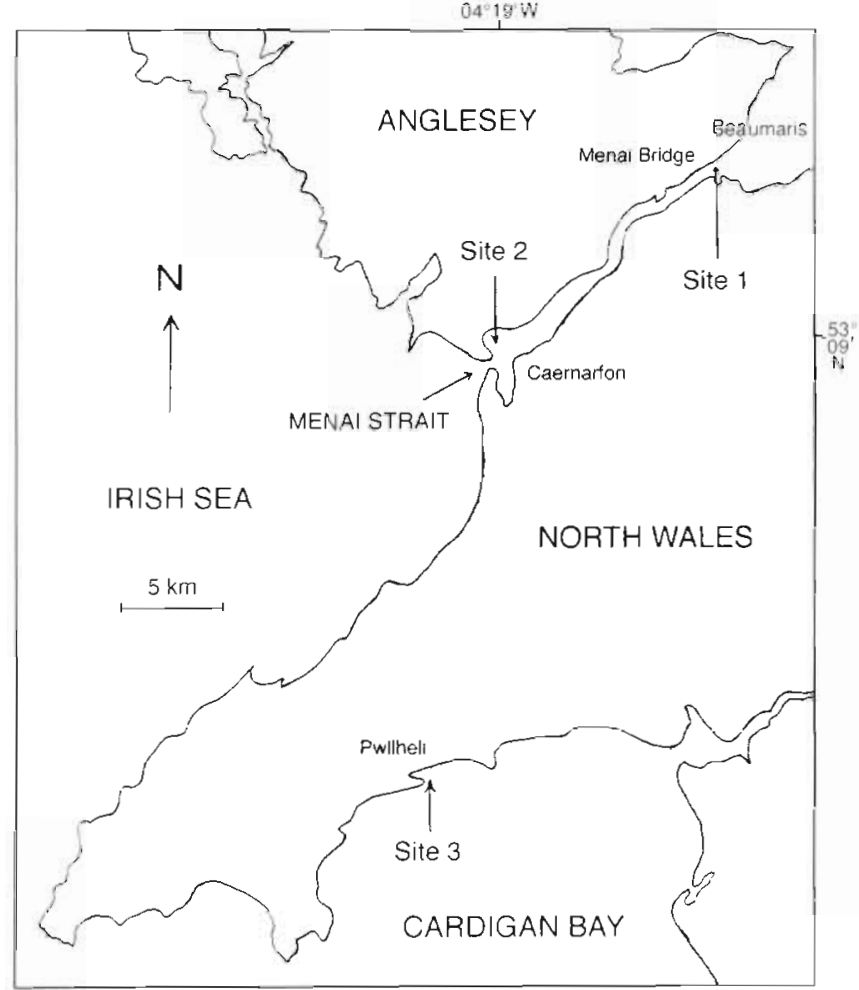

Fig. 1 Menai Strait and Cardigan Bay coasts of North Wales, UK, showing sampl..ng sites

(Fig, 1). These locations were chosen to determine whether the timing of the tidal migration varies spatially and if the behaviour is associated with local hydrodynamic conditions such as the strong residual current in the Menai Strait (Harvey 1968, Sherwin 1992) The tides in the Menai Strait and Cardigan Bay are typically semidiurnal with a period of approximately $12.4 \mathrm{~h}$. Details of the height and time of the tides were obtained from Menai Strait Tidal Tables 1994 and from the Laver Liverpool Tide Table 1994.

The zoea larvae of Carcinus maenas were collected in plankton tows ( $50 \mathrm{~cm}$ diam nets, $0.2 \mathrm{~mm}$ mesh size) conducted from a small boat. In order to obtain sufficient numbers of larvae for an actograph experiment, sampling was normally carried out for 2 to $3 \mathrm{~h}$. However, the duration of each tow was limited to no more than 15 min to minimize possible damage to the larvae. Samples were immediately transferred to the laboratory and the zoea-1 larvae of C. maenas separated out and identified, following the descriptions of Williamson (1903) and Rice \& Ingle (1975). Indeed in the sampling areas, during the summer peak breeding season, most of zoea larvae in the samples were stage 1 zoeae of $C$. maenas, reflecting the abundance of the crab in the area. No attempt was made to determine the moult stage of the first zoeae, but it was noted that generally no more than $10 \%$ of larva had moulted to zoea- 2 by 
the end of the experiments. Separation of appropriate larvae was time-consuming but no more than $12 \mathrm{~h}$ elapsed between the collections and the start of an experiment. Effort was made to minimize the temperature changes during the transfer and sorting and these were generally less than $6^{\circ} \mathrm{C}$, a difference which was shown in preliminary experiments not to affect the phase of zoea vertical migration rhythms.

Recording of migration rhythm: After sorting, larvae in batches of several hundreds were placed in an infra-red light actograph similar to that described by Hough \& Naylor (1992). This consisted of a chamber containing seawater with 2 sets of 4 infra-red transmitters and receivers in an array on each side of the chamber. The chamber was constructed of 6 mm transparent Perspex with interior dimensions $40 \mathrm{~cm}$ high, $15 \mathrm{~cm}$ wide and $5 \mathrm{~cm}$ from front to back. Two sets of 4 infrared transmitters and receivers, operating from front to back across the narrowest dimension of the chamber, were so arranged that one set of the transmitters and receivers was placed just below the water surface and the other just above the bottom. In this way, larval swimming activity on the top and bottom of the chamber was monitored simultaneously.

During the experiments, an event was recorded each time an infra-red light beam was interrupted by larvae swimming across it. All infra-light channels were monitored by a BBC model B microcomputer and, every $15 \mathrm{~min}$, the cumulative sum of beam interruptions in each channel was loaded to a cassette recorder and recorded on tape. A header-tank with a pipe of $1.0 \mathrm{~mm}$ diameter inner bore provided very slow, drop by drop fresh seawater supply (approx. $150 \mathrm{ml} \mathrm{h}^{-1}$ ) into one end of the chamber, and an outflow pipe was placed at the other end, protected by a mesh panel of $0.2 \mathrm{~mm}$ aperture to prevent loss of larvae. The fresh seawater supply not only maintained water quality, but also stabilized the water level in the chamber, avoiding loss by evaporation. Control experiments showed that the slow water flow did not affect larval migration behaviour.

All experiments were carried out in constant darkness, allowing a 1 to $2 \mathrm{~h}$ acclimation period before recording began. Once an experiment started, the whole system was left undisturbed whilst recordings were made and larvae were not fed during the experiments. Survival rate of larvae varied between experiments, but normally, if an experiment was run for less than $4 \mathrm{~d}$, more than half of the larvae survived. During all experiments, water temperature in the experimental chamber was maintained at $16 \pm 1^{\circ} \mathrm{C}$ and salinity varied between 32 and $34 \%$. At the sampling sites during the period of the experiments, field seawater temperature and salinity normally varied between 12 and $17^{\circ} \mathrm{C}$ and between 30 and $34 \%$, respectively.
Data treatment: Generally, the pattern of records was consistent between the 4 channels in each block of sensors. Therefore, unless there was an obvious malfunction in a single channel, records of the 4 channels in a same block were summed and plotted as 'swimming activity in top channels' and 'swimming activity in bottom channels' against elapsed time. Data plots are of original data and of periodogram analyses based on repeated 'Buys-ballot' form-estimates. Calculations are made of the variance of raw data points grouped in standard units over each period length being tested for. A function of this variance (usually standard deviation) is then plotted against period length to produce a graphical periodogram. High values of the periodogram statistic occur when the period under investigation approximates to the periodicity inherent in the raw data. Significant periodicity is assumed when the periodogram statistic of raw data for a given period is greater than the upper $95 \%$ confidence limit of a 'periodogram' (a regression line for which hyperbolic confidence intervals can be plotted) derived after randomizing the original data. Full details of periodogram procedure are given in Williams \& Naylor (1978).

Surface plankton sampling. Repeated surface plankton samples were taken at Site 2, Traeth Malynog, by towing a plankton net of $50 \mathrm{~cm}$ diameter, $0.2 \mathrm{~mm}$ mesh size at a constant speed (approximate 2.5 knots) at a depth of no more than $1 \mathrm{~m}$ for $15 \mathrm{~min}$ across the sheltered south facing bay, using a small boat. The samples were taken at different stages of the tide over a tidal cycle at different semilunar and diel phases during May to July 1994. Temperature and salinity were also recorded. The time interval between samples was not uniform but generally it was no more than $2 \mathrm{~h}$.

Plankton samples were fixed in $4 \%$ formalin immediately upon collection. Entire samples were searched for zoea-1 larvae of Carcinus maenas and numbers counted in the laboratory.

\section{RESULTS}

\section{Larval tidal vertical migration rhythms in the laboratory}

Clear circatidal vertical migration rhythms were present in all experiments using freshly collected zoea-1 larvae of Carcinus maenas kept in constant conditions in the laboratory. Peaks of swimming activity recurred at approximately $12.4 \mathrm{~h}$ intervals in records of both top and bottom channels in any one experiment. Moreover, the peaks and troughs were always reciprocal between the records at the surface and bottom of the test chamber, indicating that larvae moved up and down periodically in the chamber. Figs. 2A to $6 \mathrm{~A}$ show examples of the results. Periodogram analysis con- 

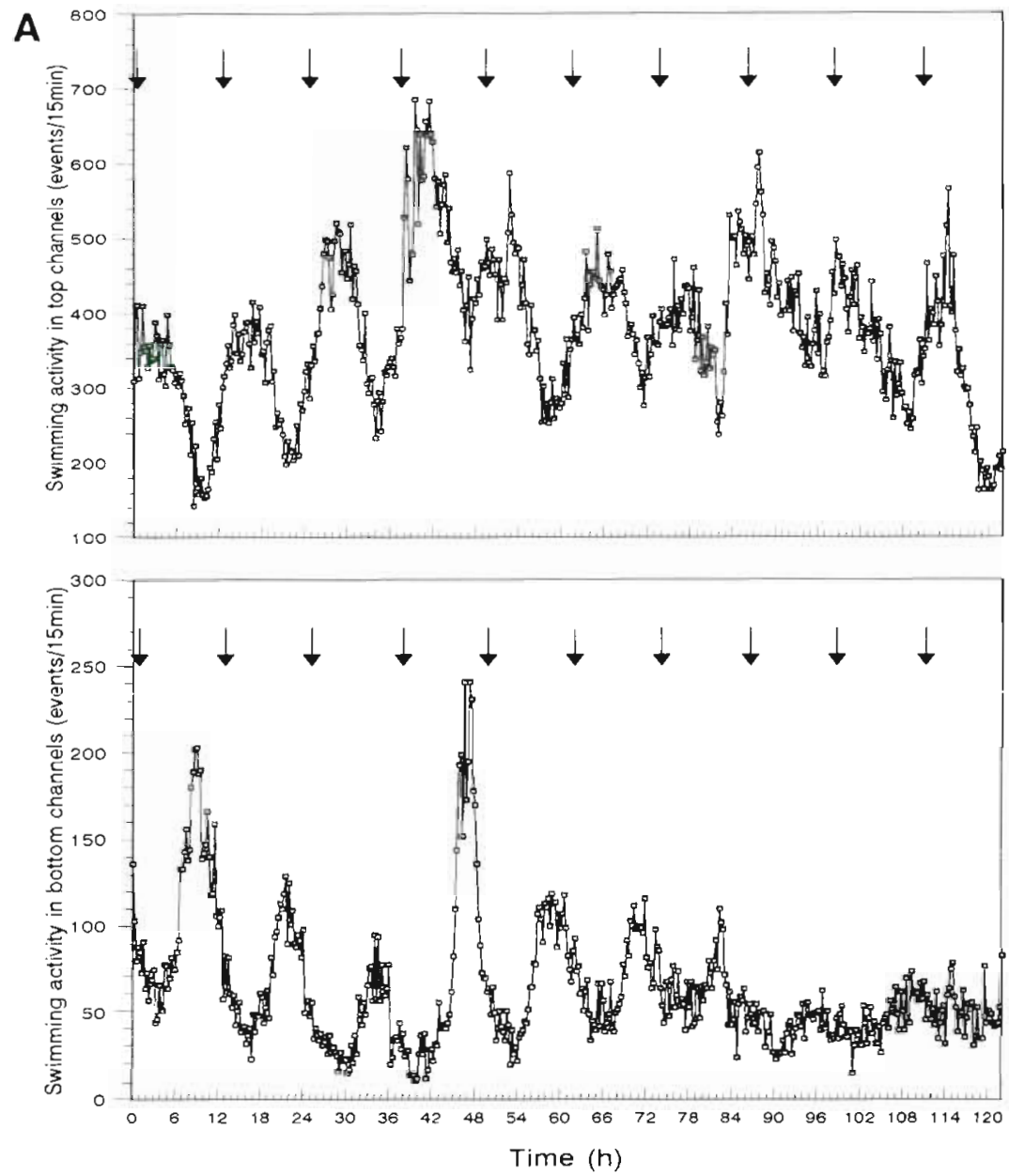

Fig. 2. Carcinus maenas. (A) Swimming activity records of field-caught zoea-1 larvae showing tidal vertical migration rhythms in constant laboratory conditions. Upper and lower part of the graph represent records near the surface and near the bottom of a vertical chamber, respectively. Arrows show times of expected high tides at the collection site. The experiment started at 1:00 $\mathrm{h}, 14$ June 1994, with an initial number of 800 freshly collected zoea-1 larvae. The larvae were collected from Site 1, at the northeast end of the Menai Strait during a spring tide, and 745 larvae survived when the experiment stopped 5 d later (B) Periodogram analysis of each of the data sets presented in A, with $95 \%$ confidence limits derived after randomization of the original data

B
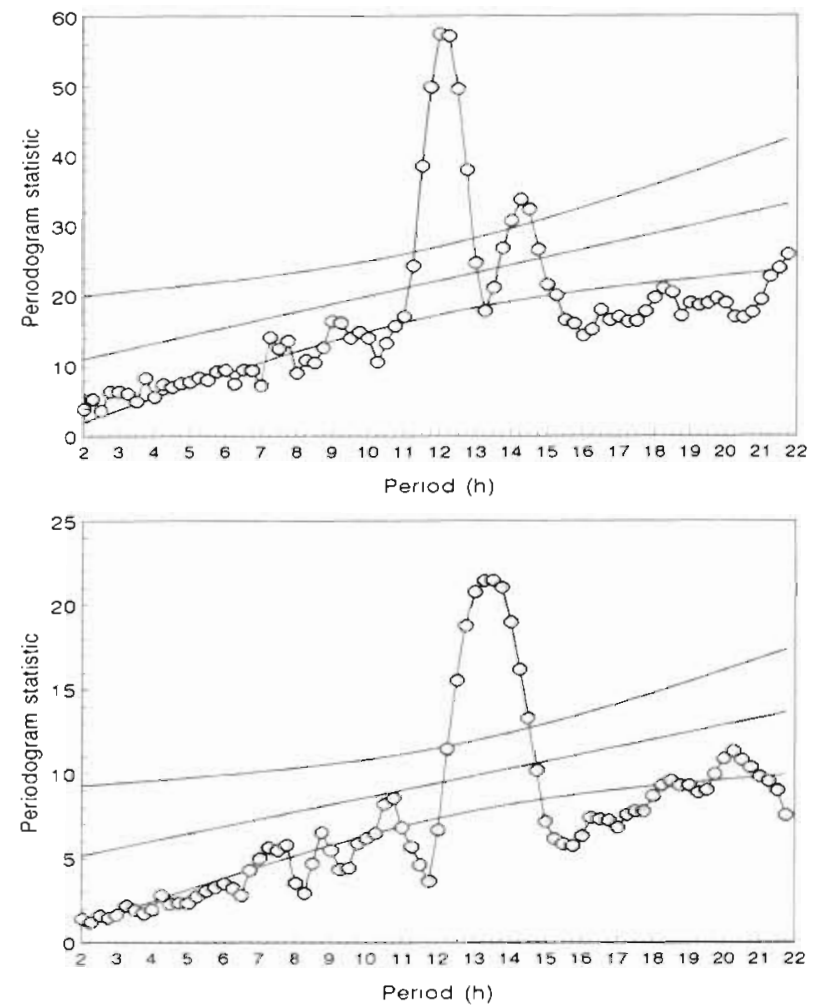

firmed that the rhythms in all experiments were circatidal (Figs. 2B to 6B).

Though most of the experiments were terminated after 5 or 6 tidal cycles, Fig. 2A shows a prolonged experiment in which, even though the larvae were starved throughout, the rhythm persisted for 10 tidal cycles without excessive damping. None of the records showed any indication of circadian modulation of the endogenous circatidal rhythms (Figs. 2A to 6A).

In all experiments, peaks of abundance at the top of the vertical test chamber consistently occurred soon after expected high tides, i.e. during expected ebbing phases. Reciprocally, abundance at the bottom of the chamber always occurred during expected flood tides. The phase relationship between the timing of the vertical migration and the local tidal cycle was the same in larvae sampled at different stages of the spring/neap cycle and from sites where the tidal phase and residual flows are different. For example, Figs. 2A to $4 \mathrm{~A}$ demonstrate that this was so in larvae collected from Site 1 (Fig. 1) at a spring tide, after springs and after neaps. Similar results are illustrated in Figs. 5A \& 6A using larvae collected from Site 2 after neaps and from Site 3 (Fig. 1) at a neap tide. 
Fig. 3. Carcinus maenas. (A) Swimming activity records of field-caught zoed-1 larvae showing tidal vertical migration rhythms in constant laboratory conditions. The experiment started at 0:00 h, 17 May 1994, with an initial number of 600 freshly collected zoea-1 larvae. They were collected from Site 1 after spring tides and 469 larvae survived when the experiment stopped. (B) Periodogram analysis of the data presented in $A$. Symbois and further detalls as in Fig. 2 legend
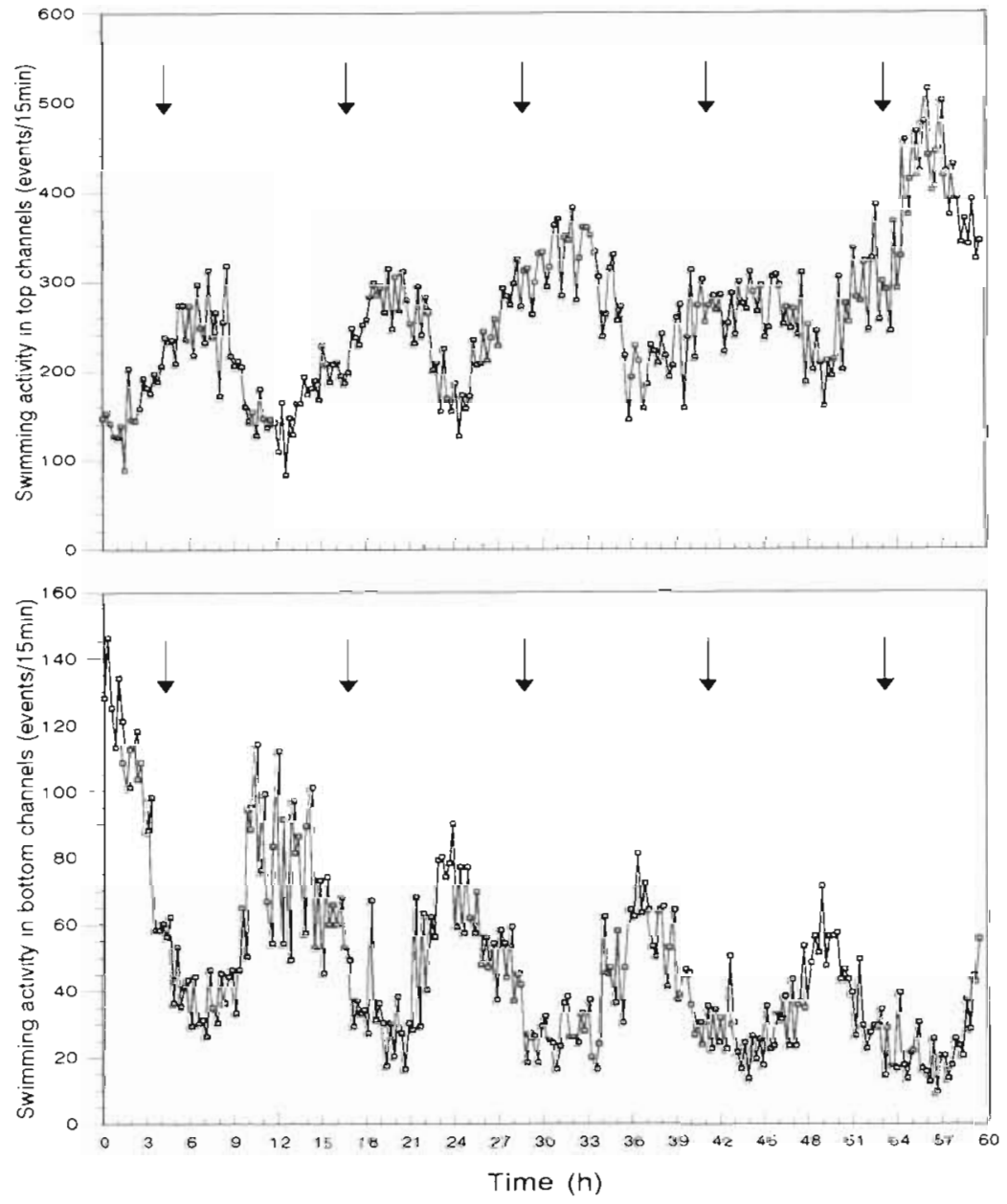

\section{Larval abundance in coastal surface waters}

Fig. $7 \mathrm{~A}-\mathrm{E}$ shows abundance of first stage zoeae of Carcinus maenas in surface plankton tows over the tidal cycle at Site 2 during April to July 1994. The samples were taken over approximately 1 tidal cycle $(12 \mathrm{~h})$ at different stages of the semilunar and diel cycles to eliminate any bias due to spring/neap or day/night differences. Fig. 7A, D shows results of sampling during daytime neap tides, Fig. $7 \mathrm{~B}$ during a nighttime neap tide, Fig. $7 \mathrm{C}$ during a nighttime spring tide and Fig. $7 \mathrm{E}$ after springs at nighttime. Clearly, in most cases, significantly fewer zoea-1 larvae were caught around low tides, but numbers increased just before high tide and reached a peak after that time. The pattern appears consistent regardless of the sampling date and the stage of spring/neap and diel cycle (Fig $7 \mathrm{~A}-\mathrm{E}$ ), and is summarized from pooled data in Fig 8. This observed pattern in field catches fits well with laboratory records of vertical migration in the actograph (see Figs. 2A to 6A), providing evidence that tidal vertical migration exists in the field and that larvae ascend to surface most abundantly at the early phase of ebb tides.
B
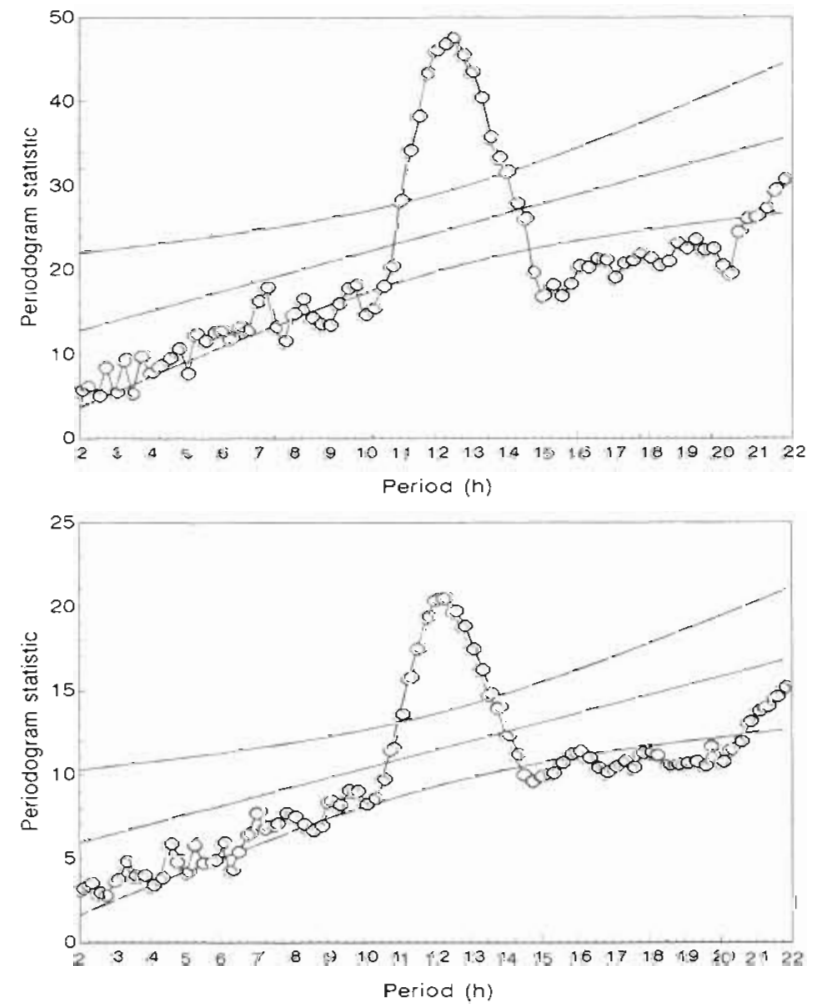

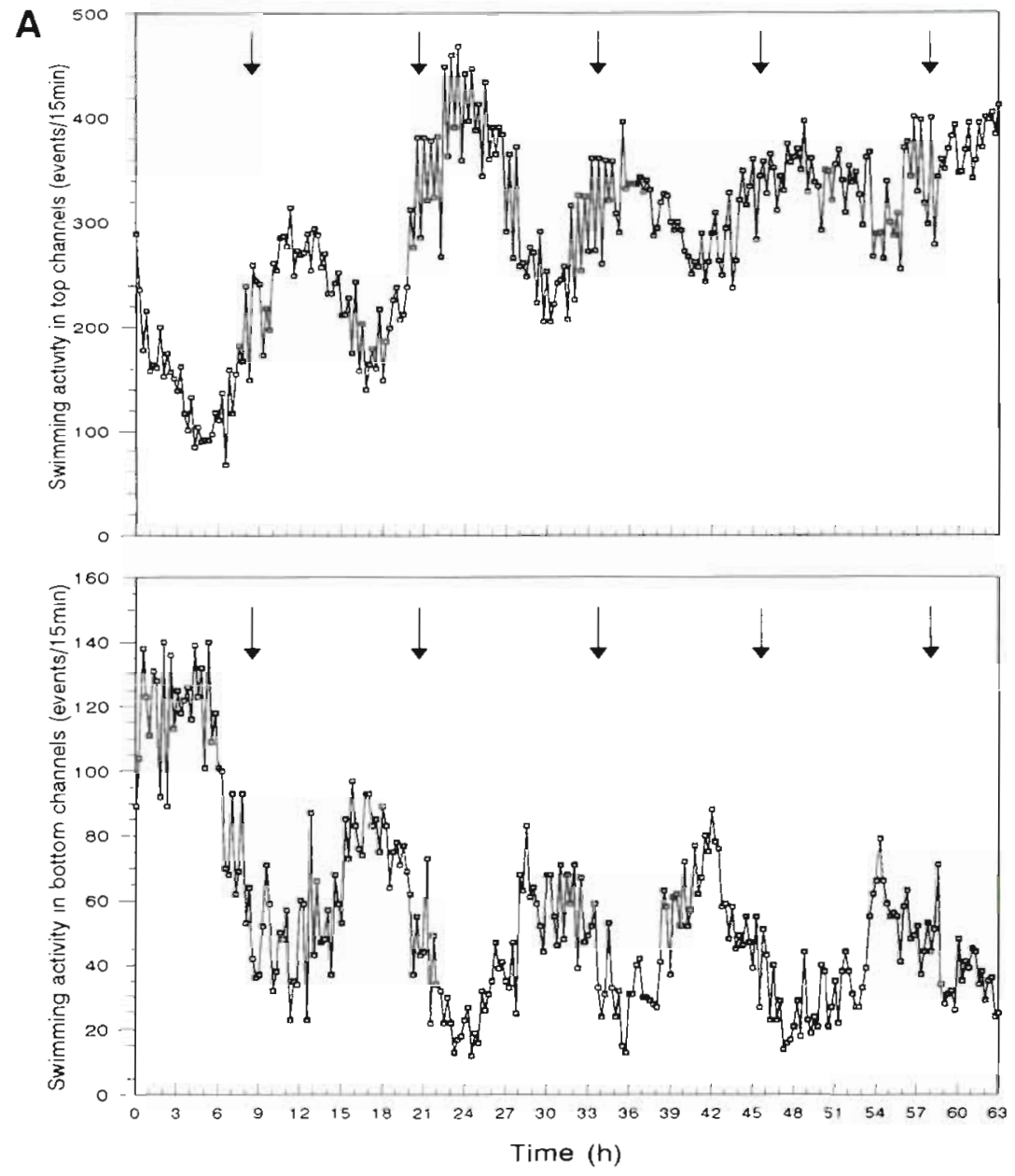

Fig. 4. Carcinus maenas. (A) Swimming activity records of field-caught zoea-1 larvae showing tidal vertical migration rhythms in constant laboratory conditions. The experiment started at 1:00 h, 24 May 1994, with an initial number of 825 freshly collected zoea-1 larvae. They were collected from Site 1 after neap tides and 700 larvae survived when the experiment stopped. (B) Periodogram analysis of the data presented in $A$. Symbols and further details as in Fig. 2 legend

\section{B}
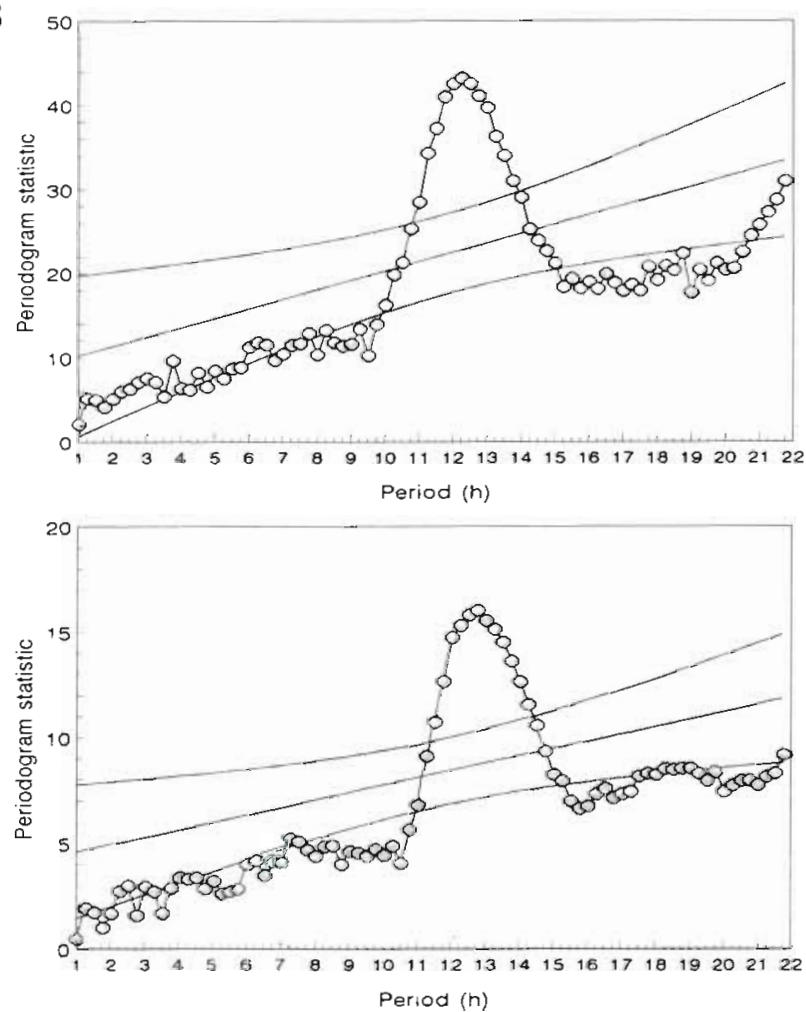

\section{DISCUSSION}

Present laboratory and field results together suggest that, in the field, newly released zoea larvae of Carcinus maenas undergo endogenously controlled tidal vertical migration, whereby they rise to the surface during early ebbing tides and remain deeper at low tide and the flood tides, regardless of semilunar and diel state. In shallow coastal seas, the predominant movement of water is often due to the tide (Hill 1995) and UK shelf seas, including the study area, are characterized by this feature (Prandle 1991. Tomczak \& Godfrey 1994). As the velocity of tidal currents decreases with depth and sharply decreases to zero within a few meters to the sea bed, interaction with such oscillatory tidal flows by vertical migration which is specifically synchronized with tide period could lead to unidirectional transport of the migrants (Hill 1991a, b, 1995). In the present locality, since slack water occurs about or slightly earlier than the time of high tide in the study areas (Sherwin 1992), it seems reasonable to postulate that the larvae which repeatedly rise to the surface after predicted high waters experience ebb 
Fig. 5. Carcinus maenas. (A) Swimming activity records of field-caught zoea-1 larvae showing tidal vertical migration rhythms in constant laboratory conditions. The experiment started at 23:30 h, 23 June 1994, with an initial number of 480 freshly collected zoea-1 larvae. They were collected from Site 2, at the southwest end of the Menai Strait after neaps. Due to water fouling, most larvae were dead when the experiment stopped. (B) Periodogram analysis of the data presented in $A$. Symbols and further details as in Fig. 2 legend
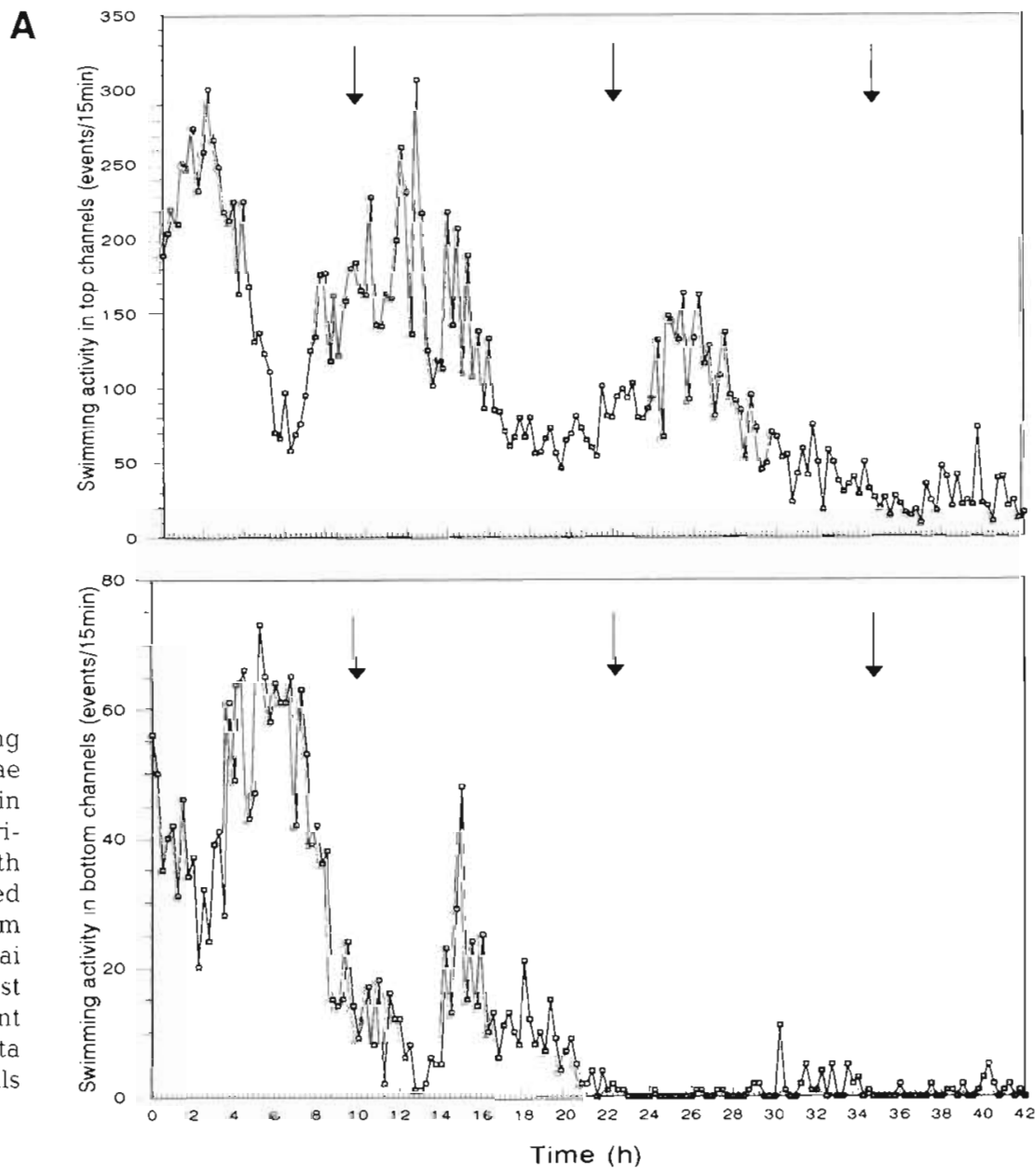

tide flows and are preferentially transported seaward by the across-shelf component of the ebb flows. Indeed, since ebb-phased upward swimming occurred in newly released Carcinus zoeae from all localities studied, the inherited pattern of vertical migration behaviour (Zeng \& Naylor 1994) is considered to be adaptive to general tidal conditions in coastal waters rather than to specific hydrodynamic conditions in a particular area. Such a hypothesis could certainly be tested by further detailed distributional studies of such larvae in Menai Straits and adjacent open coasts. However, whether or not that hypothesis is validated in a particular area, the observed vertical migration behaviour should prevent potential stranding of zoea larvae in inshore areas by maintaining larvae near the surface as the tide falls. The latter interpretation would certainly be generalizable, consistent with the widespread distribution of adult $C$. maenas on shores of various hydrodynamical types in Northwest Europe.

In Carcinus maenas, though the biology and ecology of adults have been extensively studied (Broekhuysen 1936. Naylor 1962, Crothers 1968, Klein-Breteler 1975. 1976, Thiel \& Dernedde 1994), field investigations of
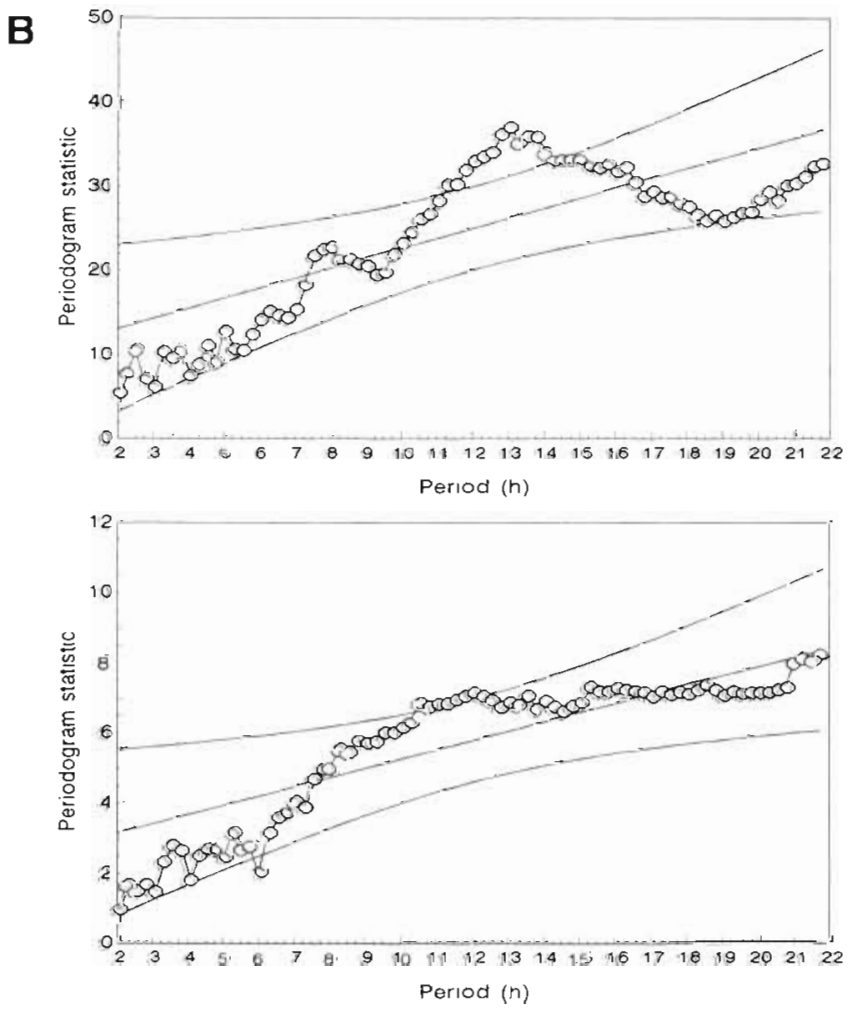

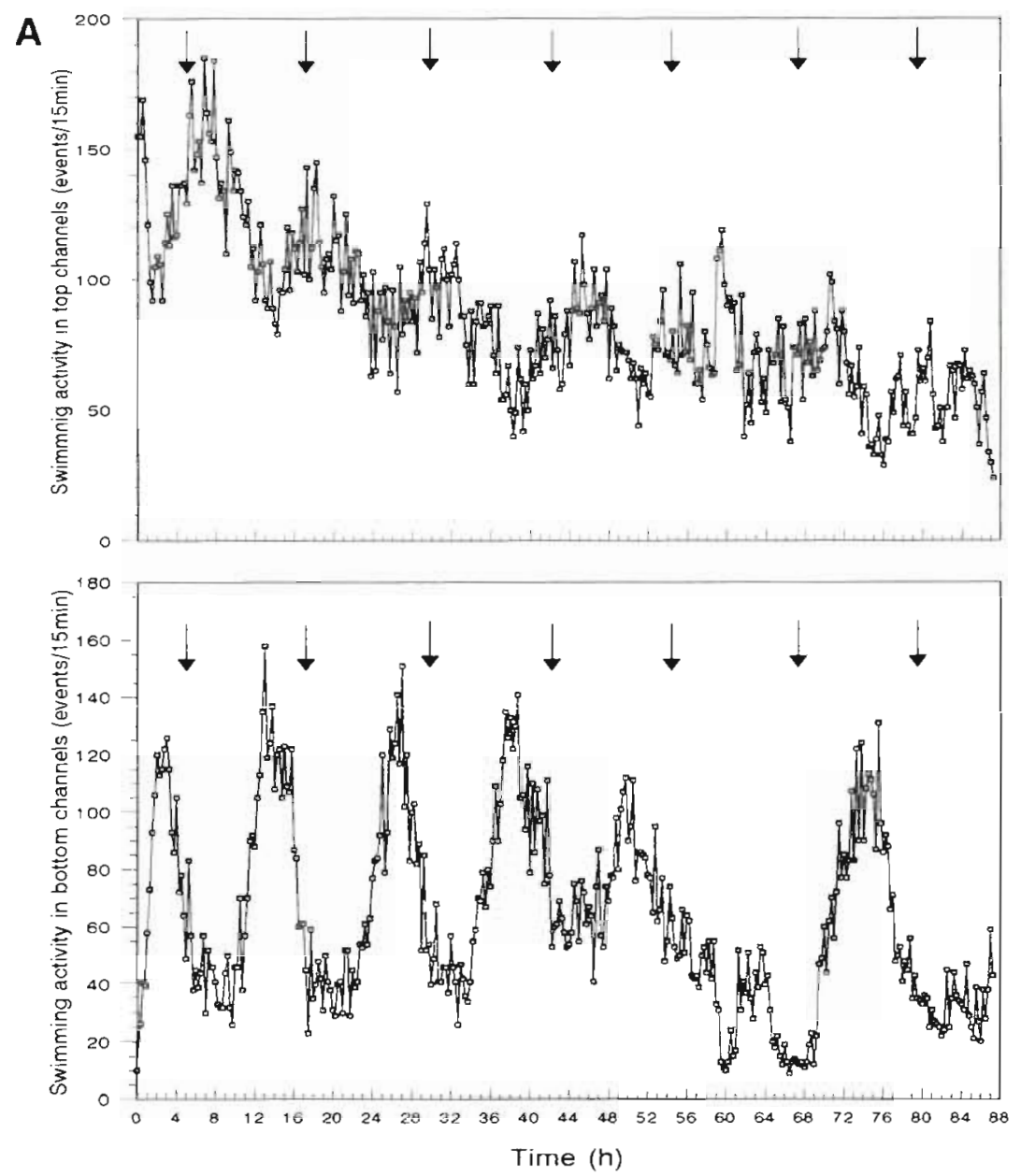

Fig. 6. Carcinus maenas. (A) Swimming activity records of field-caught zoea-1 larvae showing tidal vertical migration rhythms in constant laboratory conditions. The experiment started at 2:00 h, 7 July 1994, with an initial number of 800 freshly collected zoea-1 larvae. They were collected from Site 3, Pwllheli in Cardigan Bay, during a neap tide and 450 larvae survived when the experiment stopped. (B) Periodogram analysis of the data presented in A. Symbols and further details as in Fig. 2 legend

B
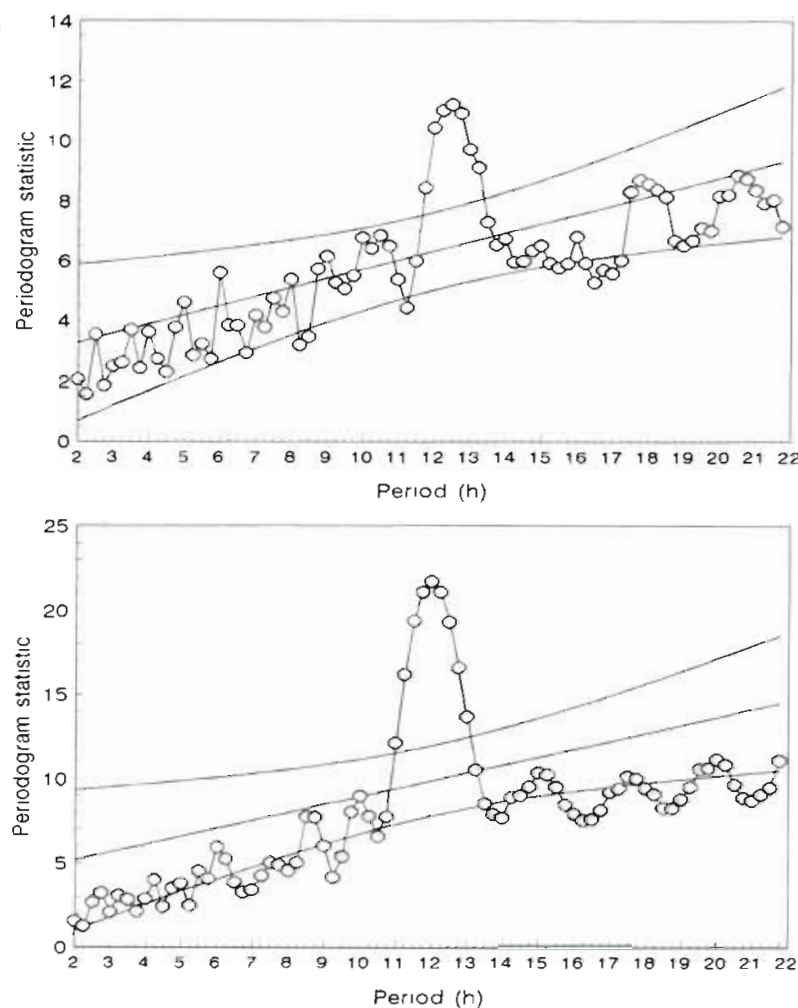

larval dynamics are rare. Here we present evidence to suggest that the newly released larvae are dispersed offshore, as was reported in an estuary (Queiroga et al. 1994)

During present field sampling in nearshore coastal waters in the breeding season, mainly first stage zoeae and megalopae were collected, but intermediate stages were rare. In addition, all megalopae in the present study from nearshore coastal waters were found very close to metamorphosis to crab stage. Among thousands of megalopa larvae collected on different dates and months, nearly $60 \%$ metamorphosed in $2 \mathrm{~d}$, more than $95 \%$ in $4 \mathrm{~d}$ and all in $7 \mathrm{~d}$ (Zeng \& Naylor in press). Since the average development time for megalopae of Carcinus maenas is reported to be $13 \mathrm{~d}$ at similar temperatures to those recorded in the present study (Dawirs 1985), it is evident that only late megalopae return and occur in coastal areas when the time of metamorphosis approaches.

Studies of hatching rhythms of Carcinus maenas also suggest offshore dispersal of the newly released larvae. We have unpublished data (Zeng \& Naylor unpubl.) which show that females of $C$. maenas exhibit an endogenously controlled hatching rhythm with 

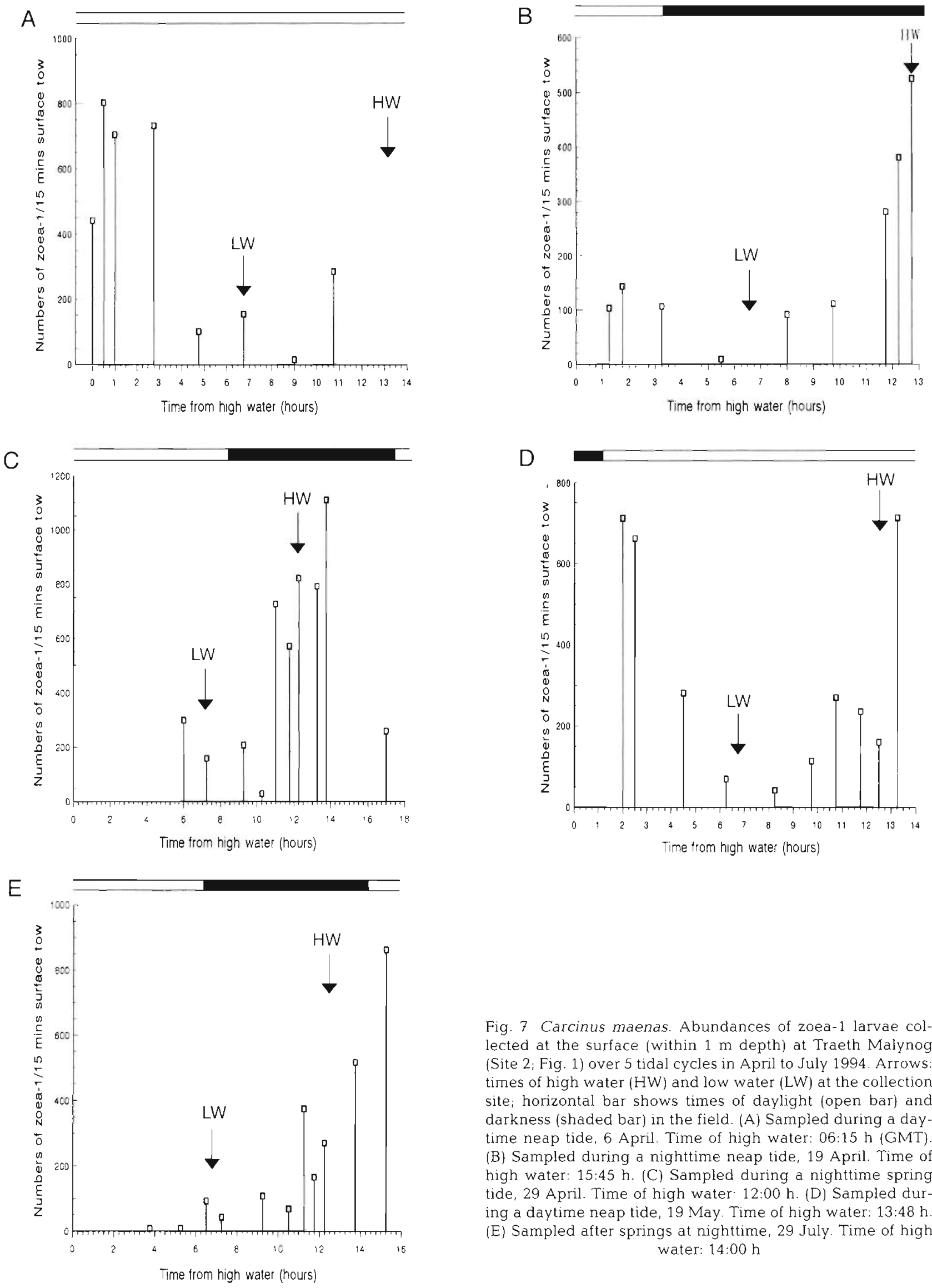

Fig. 7 Carcinus maenas. Abundances of zoea-1 larvae collected at the surface (within $1 \mathrm{~m}$ depth) at Traeth Malynog (Site 2; Fig. 1) over 5 tidal cycles in April to July 1994. Arrows: times of high water (HW) and low water (LW) at the collection site; horizontal bar shows times of daylight (open bar) and darkness (shaded bar) in the field. (A) Sampled during a daytime neap tide, 6 April. Time of high water: 06:15 h (GMT). (B) Sampled during a nighttime neap tide, 19 April. Time of high water: 15:45 h. (C) Sampled during a nighttime spring tide, 29 April. Time of high water $12: 00 \mathrm{~h}$. (D) Sampled during a daytime neap tide, 19 May. Time of high water: $13: 48 \mathrm{~h}$ (E) Sampled after springs at nighttime, 29 July. Time of high water: $14: 00 \mathrm{~h}$ 


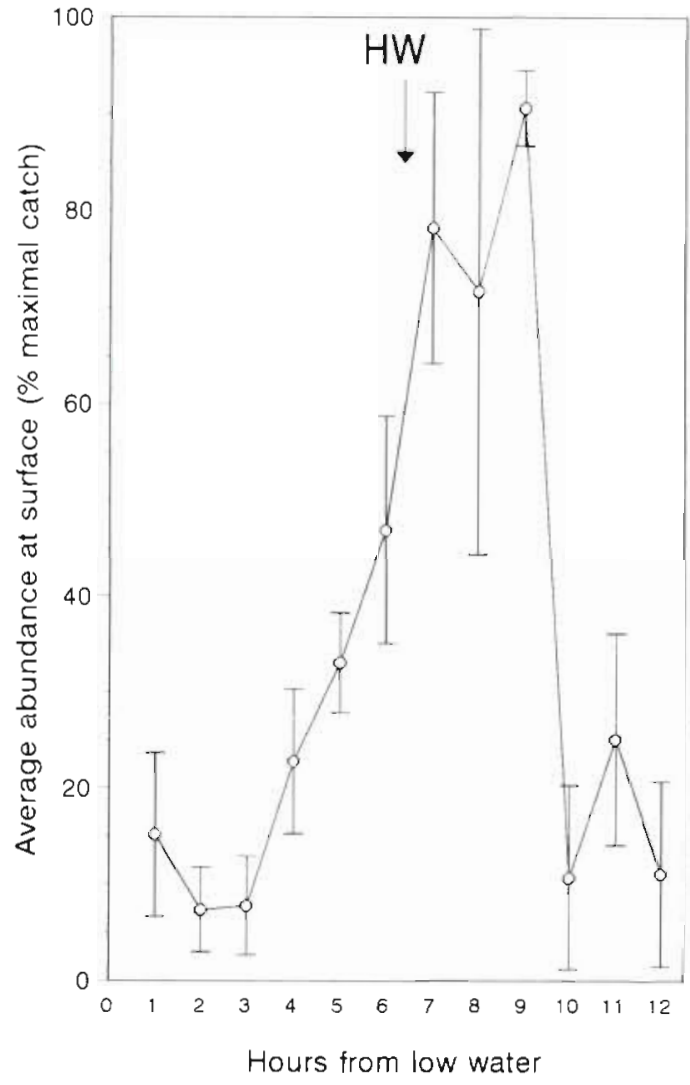

Fig. 8. Carcinus maenas. Average abundance of zoea-1 larvae near the surface (within $1 \mathrm{~m}$ depth) in relation to the tidal cycle. Error bars indicate \pm SD. All samples from Fig. 7 were pooled regardless of time and date of the collection and spring/neap cycle. Because of variations in absolute numbers of larvae caught in different samples, all data have been transformed to relative values by dividing by the maximum catch during the same sampling period before pooling. Samples were rounded up to the nearest hour

hatching taking place mainly at nocturnal high tide. Apparently, high tide hatching enhances offshore dispersal of the larvae. In addition, in a study of effects of salinity and temperature on larval survival and development of C. maenas, Nagaraj (1993) reported that for first stage zoeae from the Isle of Man, close to present study areas, the highest survival rates were in full strength seawater $(35 \%)$. Thus, all available evidence suggests that the newly released zoea larvae of $C$. maenas undertake offshore transport and that development takes place away from the coastal zone, to which the megalopae return a few days before metamorphosis to the crab stage. The tidal vertical migration rhythms of ascent during ebbing tides reported in the present study would reduce the risk of inshore stranding and thus enhance the process of offshore dispersal of the newly released larvae.

Although larval release around nocturnal high tides may account for increased zoea abundance near the sur- face just after nighttime high tide (Fig. 7A, B, C), it is clear that abundance near the surface also increased during daytime ebbing tides (Fig. 7D, E), leading to the conclusion that larval abundance patterns observed in the field do reflect larval endogenous migration rhythms.

Compared to open coast populations, larval movements of estuarine Carcinus maenas are better understood. Queiroga et al. (1994) concluded that zoeae of $C$. maenas in a Portuguese estuary were flushed seaward soon after hatching, consistent with the findings of Nagaraj (1993) that low salinity typically encountered in estuaries could be fatal to Carcinus zoea larvae. Therefore, export of newly released larvae and reinvasion of postlarvae or juveniles is suggested as a general mechanism of recruitment by this species in estuaries (Nagaraj 1993, Queiroga et al. 1994). Whether newly released zoeae of estuarine $C$. maenas exhibit tidal rhythms of vertical migration is not known, but upward swimming at the tidal ebb, as reported here, would certainly enhance export of larvae from an estuary.

The phase of endogenous tidal vertical migration in zoeae of Carcinus maenas is opposite to that reported in zoeae of Rhithropanopeus harrisii for facilitating estuary retention (Cronin \& Forward 1979). However, the migration phase in each case remained constant over the spring/neap cycle (Cronin \& Forward 1979, 1982). For $R$. harrisii larvae, this is correlated well with the field observations that larvae of all zoea stages of the crab are normally retained in the upper reaches of estuaries (Williams 1971, Sandifer 1973, 1975, Cronin 1982). In contrast, flexibility in phasing of the time of endogenous peak activity over the semilunar cycle and with position along the estuary has been demonstrated for the estuarine copepod Eurytemora affinis (Hough \& Naylor 1992). These authors reported that copepods collected during spring tides of increasing amplitude showed peak activity during the expected flood tide, while those sampled on spring tides of decreasing amplitude or towards the limit of tidal influence displayed peak activity during the expected ebb tide. The phase-lability was attributed to fine-tuning of behaviour correlated with the field observed concentration of this copepod in middle reaches of an estuary which varies only by a shift upstream at spring tides and downstream at neaps (Hough \& Naylor 1991, 1992). In the present study of Carcinus zoea larvae, consistent timing of vertical migration over the semilunar cycle is also in agreement with the hypothesis that the behaviour is adaptive for avoidance of stranding inshore and hence enhancement of offshore dispersal of the larvae.

In the crab Rhithropanopeus harrisii, it was found that first stage zoeae from an estuary with strong semidiurnal tides exhibited tidal vertical migration rhythms, whilst in larvae from an estuary with aperiodic tides, no clear migration rhythm was expressed 
(Cronin \& Forward 1983). In contrast, there were no differences in the rhythmic behaviour of first stage zoeae of Carcinus maenas in the present study related to local differences in tidal timing or residual flows. Again, the consistency of behaviour irrespective of locality supports the hypothesis that the behaviour is generally adaptive for facilitating offshore dispersal of the larvae and suggests that the behaviour is likely not to be a local phenomenon, but is widespread in this crab species.

The synchronization process of circatidal rhythms in intertidal animals is well documented (for reviews see Palmer 1974, Enright 1975, DeCoursey 1983, Naylor 1985). In adult Carcinus maenas, it has been demonstrated that tidal locomotor rhythms can be entrained by various synchronizers, including changes in hydrostatic pressure, salinity, temperature and immersion/ emersion (Naylor \& Atkinson 1972, Taylor \& Naylor 1977. Naylor \& Williams 1984, Bolt \& Naylor 1985, Reid et al. 1993, Warman \& Naylor 1995). However, for planktonic organisms which remain in the water column, some of the environmental variables that are effective zeitgebers for benthic intertidal animals may have little influence. In studies related to present work, we have shown that if detached eggs of $C$. maenas were subjected to periodic water agitation in the laboratory, tidal rhythms can be entrained in subsequently hatched larvae (Zeng \& Naylor 1994). This suggests that the larval tidal clocks are probably set in phase with local tides before zoeae are released, ensuring quick transport of larvae offshore. However, the pattern, strength and synchrony of the tidal migration rhythms are likely to be further entrained by environmental factors in the water column after release.

Acknowledgements. We thank Dr A. Aagaard for graciously providing the periodogram analysis computer program. Drs A. E. Hill and T. J. Sherwin have provided much helpful discussion. Mr G. P. Jones helped in field sampling. This work was carried out during a joint Chinese British Governmentfunded TC fellowship to $C . Z$. and the research formed a part of his doctoral dissertation

\section{LITERATURE CITED}

Berril M (1982) The life cycle of the green crab Carcinus maenas at the northern end of its range. J Crust Biol 2:31-39

Bolt SRL, Naylor E (1985) Interaction of endogenous and exogenous factors controlling the activity rhythms in Carcinus maenas. J Exp Mar Biol Ecol 85:47-56

Broekhuysen GJ Jr (1936) On development, growth and distribution of Carcinides maenas (L.). Archs Néerl Zool 2 $257-399$

Brookins KG. Epifanio CE (1985) Abundance of brachyuran larvae in a small coastal inlet over six consecutive tidal cycles. Estuaries 8:60-67

Carriker MR (1951) Ecological observations on the distribution of oyster larvae in New Jersey estuaries. Ecol Monogr $21: 19-38$

Carriker MR (1961) Interrelation of functional morphology, be- haviour and autecology in early stages of the bivalve, Mercenaria mercenaria. J Elisha Mitchell Sci Soc 77:168-241

Cronin TW (1982) Estuarine retention of larvae of the crab Rhithropanopeus harrisii (Gould). Estuar Coast Shelf Sci 15:207-220

Cronin TW, Forward RB Jr (1979) Tidal vertical migration: an endogenous rhythm in estuarine crab larvae. Science 205: $1020-1022$

Cronin TW, Forward RB Jr (1982) Tidally timed behaviour: effects on larval distributions in estuaries. In: Kennedy VS (ed) Estuarine comparisons. Academic Press, New York, p 505-520

Cronin TW, Forward RB Jr (1983) Vertucal migration rhythms of newly hatched larvae of the estuarine crab, Rhithropanopeus harrisii. Biol Bull 165:139-153

Crothers JH (1968) The biology of the shore crab Carcinus maenas 2 . The life of the adult crab. Fld Stud 2:579-614

Dawirs RR (1985) Temperature and larval development of Carcinus maenas in the laboratory: predictions of larval dynamic in the sea. Mar Ecol Prog Ser 24:397-302

DeCoursey PJ (1976) Vertical migration of larval UCa in a shallow estuary. Am Zool 16:244

DeCoursey PJ (1983) Biological timing. In: Bliss DE, Mantele LH (eds) The biology of Crustacea, Vol 7. Academic Press, New York, p 107-162

De Vries MC, Tankersley RA, Forward RB Jr, Kirby Smith WW, Luettich RA Jr (1994) Abundance of estuarine crab larvae is associated with tidal hydrologic variables. Mar Biol 118:403-413

Dittel AI, Epifanio CE (1990) Seasonal and tidal abundance of crab larvae in a tropical mangrove system, Gulf of Nicoya, Costa Rica. Mar Ecol Prog Ser 65:25-34

Enright JT (1975) Orientation in time: endogenous clocks. In: Kınne $O$ (ed) Marine ecology, Vol 2. Wiley Interscience, New York, p 467-494

Enright JT, Hamner HW (1967) Vertical diurnal migration and endogenous rhythmicity. Science 157:937-941

Epifanio CE (1988a) Transport of invertebrate larvae between estuaries and the continental shelf. Am Fish Soc Symp 3: $104-114$

Epifanio CE (1988b) Transport of crab larvae between estuaries and the continental shelf. In: Jansson BO (ed) Lecture notes on coastal and estuarine studies, Vol 22. SpringerVerlag, Berlin, p 291-305

Epifanio CE, Valenti CC, Pembroke AE (1984) Dispersal and recruitment of blue crab larvae in Delaware Bay, USA. Estuar Coast Shelf Sci 18:1-12

Harris JE (1963) The role of endogenous rhythms in vertical migration. J Mar Biol Ass UK 43:153-166

Harvey JG (1968) The flow of water through the Menai Strait. Geophys J R Astron Soc 15:517-528

Hill AE (1991a) A mechanism for horizontal zooplankton transport by vertical migration in tidal currents. Mar Biol 111:485-492

Hill AE (1991b) Vertical migration in tidal currents. Mar Ecol Prog Ser 75:39-54

Hill AE (1995) The kinematical principles governing horizontal transport induced by vertical migration in tidal flows. J Mar Biol Ass UK 75:3-13

Hobbs RC, Botsford LW (1992) Diel vertical migration and timing of metamorphosis of larvae of the Dungeness crab Cancer magister. Mar Biol 112:417-428

Hobbs RC, Botsford LW, Thomas A (1992) Influence of hydrographic conditions and wind forcing on the distribution and abundance of Dungeness crab, Cancer magister, larvae. Can J Fish Aquat Sci 49:1379-1388

Hough AR, Naylor E (1991) Field studies on retention of the 
planktonic copepod Eurytemora affinis in a mixed estuary Mar Ecol Prog Ser 76:115-122

Hough AR, Naylor E (1992) Endogenous rhythms of circatidal swimming activity in estuarine copepod Eurytemora affinis (Poppe). J Exp Mar Biol Ecol 161:27-32

Johnson DF (1985) The distribution of brachyuran crustacean megalopat in the waters of the York River, lower Chesapeake Bay and adjacent shelf: implications for recruitment. Estuar Coast Shelf Sc1 20:693-705

Johnson GE, Gonor JJ (1982) The tidal exchange of Callianassa californiensis (Crustacea, Decapoda) larvae between the ocean and the Salmon River estuary, Oregon Estuar Coast Shelf Sci 14:501-515

Klein-Breteler WCM (1975) Growth and moulting of juvenile shore crabs, Carcinus maenas, in a natural population. Neth J Sea Res 9:86-99

Klein-Breteler WCM (1976) Settlement, growth and production of the shore crabs, Carcinus maenas, on tidal flats in the Dutch Wadden Sea. Neth J Sea Res 10:354-376

Little KT, Epifanio CE (1991) Mechanisms for the reinvasion of an estuary by two species of brachyuran megalopae Mar Ecol Prog Ser 68:235-242

Longhurst AR (1976) Vertical migration. In: Cushing DH, Walsh JJ (eds) The ecology of the sea. Sanders Co. Philadelphia, p 116-137

McConaugha JR (1988) Export and reinvasion of larvae as regulators of estuarine decapod populations. Am Fish Soc Symp 3:90-103

McConaugha JR (1992) Decapod larvae: dispersal, mortality, and ecology. A working hypothesis. Am Zool 32:512-523

McConnaughey RA, Armstrong DA, Hickey BM, Gunderson DR (1992) Juvenile Dungeness crab (Cancer magister) recruitment variability and oceanic transport during the pelagic larval phase. Can J Fish Aquat Sci 49:2028-2044

Mense DJ, Wenner EL (1989) Distribution and abundance of early life history stages of the blue crab Callinectes sapidus, in tidal marsh creeks near Charleston, South Carolina. Estuaries 12:157-168

Nagaraj M (1993) Combined effects of temperature and salinity on the zoea development of the green crab, Carcinus maenas (Linnaeus, 1758) (Decapoda: Portunidae). Scientia Mar 57:1-8

Naylor E (1962) Seasonal changes in a population of Carcinus maenas (L.) in the littoral zone. J Anim Ecol 31:601-609

Naylor E (1985) Tidally rhythmic behaviour of marine animals. Symp Soc Exp Biol 39:63-93

Naylor E, Atkinson RJA (1.972) Pressure and the rhythmic behaviour of inshore marine animals. Symp Soc Exp Biol 26:395-415

Naylor E, Williams BG (1984) Environmental entrainment of tidally rhythmic behaviour in marine animals. Zool J Linn Soc 80:201-208

Olmi EJ (1994) Vertical migration of blue crab Callinectes sapidus megalopae: implications for transport in estuaries. Mar Ecol Prog Ser 113:39-54

Palmer JD (1974) Biological clocks in marine organisms: the control of the physiological and behavioral tidal rhythms. John Wiley \& Sons, New York

Prandle D (1991) A new view of near-shore dynamics based on observation from $\mathrm{HF}$ radar. Prog Oceanogr 27:404-438

Provenzano AJ, McConaugha JR Jr, Philips KB, Johnson DF, Clark J (1983) Vertical distribution of first stage larvae of the blue crab, Callinectes sapidus, at the mouth of Chesapeake Bay. Estuar Coast Shelf Sci 16:489-499

Querroga $H$, Costiow JD, Moreira MH (1994) Larval abundance patterns of Carcinus maenas (Decapoda, Brachyural in Canal de Mira (Rio de Aveiro, Portugal). Mar Ecol
Prog Ser 111:63-72

Reid DG. Warman CG, Naylor E (1993) Ontogenetic changes in zeitgeber action in the tidally rhythmic behavior of the shore crab Carcinus maenas. In: Aldrich JC (ed) Quantified phenotypic responses in morphology and physiology. JAPAGA, Ashford, Dublin, p 129-133

Rice AL, Ingle RW (1975) The larval development of Carcinus maenas (L.) and C. mediterraneus Czerniavsky (Crustacea. Brachyura, Portunidae) reared in the Iaboratory, Bull Br Mus Nat Hist (Zool) 28:103-119

Rothlisberg PC, Church JA, Fandry CB (1995) A mechanism for near-shore concentration and estuarine recruitment of post-larval Penaeus plebejus Hess (Decapoda, Penaeidae). Estuar Coast Shelf Sci 40:115-138

Sandifer PA (1973) Distribution and abundance of decapod crustacean larvae in the York River estuary and adjacent lower Chesapeake Bay, Virginia, 1968-1969. Chesapeake Sci 14:235-257

Sandifer PA (1975) The role of pelagic larvae in recruitment to population of adult decapod crustaceans in the York River estuary and adjacent lower Chesapeake Bay, Virginia. Estuar Coast Mar Sci 3:269-279

Shanks AL (1985) Behavioral basis of internal-wave-induced shoreward transport of megalopae of the crab Pachygrapsus crassipes. Mar Ecol Prog Ser 24:289-295

Sherwin TJ (1992) Tidal currents in the Menai Strait. Prac Boat Owner 305:101-103

Tankersley RA, Forward RB Jr (1994) Endogenous swimming rhythms in two estuarine crab megalopae: implications for flood tide transport. Mar Biol 118:415-423

Taylor AC, Naylor E (1977) Entrainment of the locomotor rhythm of Carcinus maenas by cycles of salinity change. J Mar Biol Ass UK 57:273-277

Thiel M, Dernedde T (1994) Recruitment of shore crabs Carcinus maenas on tidal flats: mussel clumps as an important refuge for Juveniles. Helgoländer Meeresunters 48 : $321-332$

Tomczak M, Godfrey JS (1994) Regional oceanography: an introduction. Pergamon, Oxford

Warman CG, Naylor E (1995) Evidence for multiple, cue-specific circatidal clocks in the shore crabs Carcinus maenas. J Exp Mar Biol Ecol 189:93-1.01

Williams AB (1971) A ten-year study of meroplankton in North Carolina estuaries: annual occurrence of some brachyuran developmental stages. Chesapeake Sci 12: $53-61$

Williams JA, Naylor E (1978) A procedure for the assessment of significance of rhythmicity in time-series data. Int $\mathrm{J}$ Chronobiol 5:435-444

Williamson $\mathrm{HC}$ (1903) On the larval and early young stages and rate of growth of the shore crab Carcinus maenas (L.). Rep Fish Bd Scotl 19:136-179

Wood L, Hargis JH (1971) Transport of bivalve larvae in a tidal estuary. In: Crisp DJ (ed) Proc 4th Eur Mar Biol Symp. Cambridge University Press, Cambridge, p 29-44

Wooldridge T, Erasmus I (1980) Utilisation of tidal currents by estuarine zooplankton. Estuar Coast Mar Sci 11:107-114

Young PC, Carpenter SM (1977) Recruitment of postlarval penaeid prawns to nursery areas in Moreton Bay, Queensland. Austr J Mar Freshwat Res 28:745-773

Zeng C, Naylor E (1994) Endogenous tidal rhythm of vertical migration in newly hatched larvae of Carcinus maenas. J Mar Biol Ass UK 74:724

Zeng C, Naylor E (in press) Occurrence in coastal waters and endogenous tidal swimming rhythms of late megalopae of the shore crab Carcinus maenas: implications for onshore recruitment. Mar Ecol Prog Ser 